\title{
The Physical and Chemical Properties of Wheat Flour in Some Wheat (Triticum spp.) Varieties Grown in West Sumatera
}

\author{
Fauzan Azima, Novelina, Risma Srikandi Pane \\ \# Agricultural Technology Department, University of Andalas, Limau Manis - Padang 25163 \\ E-mail: Sweet_keyn13@yahoo.com
}

\begin{abstract}
This research aims to determine the physical and chemical properties of wheat flour in some wheat varieties grown in West Sumatra. This research used Completely Randomized Design (CRD) consisting of five treatments and three repetitions. The treatments are: A (Wheat varieties Jarissa), B (Wheat varieties Dewata), C (Wheat varieties 1247), D (Wheat varieties Selayar) and E (Wheat varieties SO1). Observation ofthe resulting flour includes analysis of physical, functional, and proximate. Physical analysis of the results obtained flour; yield varieties Jarissa (50.00\%); Dewata $(45.45 \%)$, $1247(50.00 \%)$; Selayar $(47.83 \%)$; SO1 $(47.66 \%)$. Water absorption of Jarissa varieties (65.90\%); Dewata (59.95\%), 1247 (49.27\%); Selayar (69.85\%); SO1 (51.67\%). Oil absorption of Jarissa varieties $(17.67 \%)$; Dewata $(18.33 \%), 1247$ (19.67\%); Selayar (16.00\%); SO1 (15.67\%). Gelatinization temperature of Jarissa varieties $\left(65.67^{\circ} \mathrm{C}\right)$; Dewata $\left(65^{\circ} \mathrm{C}\right)$; $1247\left(66^{\circ} \mathrm{C}\right)$; Selayar $\left(67^{\circ} \mathrm{C}\right)$; SO1 $\left(65.67^{\circ} \mathrm{C}\right)$. Chemical analysis results obtained flour; Water content of Jarissa varieties (10.02\%); Dewata (12.00\%), 1247 (14.75\%); Selayar (9.48\%); SO1 (12.24\%). Ash content of Jarissa varieties $(1.45 \%)$; Dewata $(1.75 \%)$, $1247(2.15 \%)$; Selayar (1.63\%); SO1 (1.87\%). Fat content of Jarissa varieties $(2.24 \%)$; Dewata (2.59\%), 1247 (2.50\%); Selayar (2.15\%); SO1 (2.34\%). Crude fiber content of Jarissa varieties (3.46\%); Dewata (3.11\%), 1247 $(\mathbf{2 . 5 6 \% )}$; Selayar $(\mathbf{2 . 7 3 \% )}$; SO1(3.13\%). Carbohydrates of Jarissa varieties $(\mathbf{7 1 . 5 5 \% )}$; Dewata $(67.00 \%)$, $1247(66.06 \%)$; Selayar $(\mathbf{7 3 . 6 0 \%})$; SO1 (69.59\%). Starch content of Jarissa varieties $(53.00 \%)$; Dewata $(51.92 \%)$, $1247(50.86 \%)$; Selayar $(46.08 \%)$; SO1 $(42.74 \%)$. Protein content of Jarissa varieties (14.75\%); Dewasa (16.66\%), 1247 (14.54\%); Selayar (13.13\%); SO1 (13.97\%). Glutenof Jarissa varieties (50.09\%); Dewata (13.37\%), 1247 (12.71\%); Selayar (28.57\%); SO1 (35.36\%).
\end{abstract}

Keywords - Physical Properties; Chemical Properties; Varieties of Wheat; Wheat Flour

\section{INTRODUCTION}

This Wheat (Triticum spp.) Is one type of crop grains group that lived in subtropical climates. Wheat is the most important source of carbohydrates in the world, beside that wheat also contains of protein, minerals and vitamins [1].

Wheat is one type of cereal which is quite popular and as raw materials of flour, animal feed and fermented to produce alcohol, but beside that it's also plenty used as raw materials of noodles, meatballs, bread, various types of cakes and so on. Nevertheless, until now there has been no other material as a substitute for wheat to make bread or food that can be expanded with the help of yeast because wheat is the only one type of cereals - grains that contain gluten that plays a role in development [2]. At this time all domestic flour needs to be supplied from imports in the form of wheat seed which is then processed into flour by flouring industries such as PT. Bogasari Flour Mills.

Volume of wheat seed imports are expected to continue increasing in the next couple years, in a line with the increasing population and a change in eating patterns of Indonesian people. The continued development of fast food especially in the big cities will encourage in increasing consumption of wheat flour [3].

Wheat consumption in Indonesia is quite high which average needs of wheat flour per year to 3.8 million tons. The use of wheat is almost $65 \%$ is absorbed by the small-and medium scale of food industry- $5 \%$ used by large industry and $30 \%$ used of households scale. Nowdays, wheat needs in Indonesia it depends on imports. Wheat imports are coming from the United States, Canada and Australia which is the world's largest wheat producer. Flour industry imported about 4 million tonnes of wheat seeds per year which produced 3.4 million tonnes of wheat flour. The amount of imported wheat because the wheat plants in Indonesia has not been cultivated intensively and wheat is not seen as a strategic food plants to be cultivated nationally [4].

Remember that, the increasing amount of foreign exchange that issued it's necessary to reduce dependence on imported wheat. The solutions to prevent Indonesia's wheat imports are to increase national grain production. National wheat production increased through an intensive coaching to farmers, expanding agricultural land wheat, seed superior stock, research and attract the investors [5]. 
Wheat plants can be grown at an altitude of 800 meters above sea level. The identification results by the Department of Agriculture in the highlands in Indonesia, there are 20 million hectares of potential land for development of wheat. But only two million hectares of wheat are arable land [6].

In Indonesia, The suitable locations of climatic conditions for the growth of wheat and has been used as a location for development until 2008 are Nangroe Aceh Darussalam, North Sumatra, West Sumatra, Jambi, Bengkulu, South Sumatra, Lampung, West Java, Central Java, East Java, West Nusa Tenggara, East Nusa Tenggara, West Kalimantan, East Kalimantan and South Sulawesi [7].

In 2011 the Slovak wheat has been planted in the area of West Sumatra. After planting and adaptation test and yield trials in several locations of 15 varieties obtained yields of varieties Jarissa, Dewata, 1247, Selayar and S01 are the most widely produced wheat seeds compared to other wheat varieties. It's probably only 5 varieties which is suitable and able to adapt with a new environment at this time.

Nevertheless, among all the 5 varieties, varieties of Jarissa, Dewata and 1247 that have a much higher yield than the varieties Selayar and S01. In addition a variety of Dewata and Selayar constitutes as a local wheat cultivars. Because the adaptation tests were conducted earlier by the experts in their field and have been released into the national superior wheat varieties. Where as varieties of Jarissa, 1247 and SO1 as a native varieties of Slovak, which is still being developed and are still doing the adaptation and test results before being released into national wheat varieties. From that description above, the researcher is interested in using a variety Jarissa, Dewata, 1247, Selayar and S01 as a treatment in this study.

Wheat grown in the West Sumatera area included varieties Jarissa, Dewata, 1247, Selayar and SO1 are unknown based on physical properties, chemical and nutritional content, so that there is no standard yet for what food products are suitable to be applied. For that case, it's needed to conduct the test of physical and chemical properties of each of these developed varieties of wheat.

By detecting the physical and chemical properties of the wheat flour, so it can be used as guidelines for its implementation. For a high protein flour can be used in making bread and noodles. But in making noodles unneeded development more.

Based on the explanation above, it is necessary to do a research in order to determine the physical and chemical properties of flour produced in some of the varieties grown in West Sumatra.

\section{METHODOLOGY}

\section{A. Materials and Equipment}

Raw materials used in this study were five varieties of wheat that consists of Jarissa, Dewata, 1247, Selayar and SO1 came from Alahan Panjang, West Sumatra.

The chemicals materials used for the analysis are selenium, $\mathrm{NaOH}, \mathrm{H} 2 \mathrm{SO} 4, \mathrm{KI}$, boric acid, HCL, n-hexane, alcohol 96\%, Luff, selenium mixtire, H2BO3, methyl red, petroleum ether, acetic $\mathrm{pb}, \mathrm{pp}$ indicator and distillate water.

The equipments used in this study are Blender, 80 mesh sieve, analytical balance, stove, pot, glass cup, thermometer, pot, frying pan, strainer, ampia, bowl, knife and spoon.The analysis tools used are pumpkin kjeldahl, distillation apparatus, flask, burette, ashing furnace, oven, soxhlet extraction apparatus, hot plate, desiccator, erlemeyer funnel, cup, saucer clamp, glass and other tools.

\section{B. Design}

The design used in this study is a complete random design (CRD) with 5 treatments and 3 repetitions. Data were analyzed statistically by $\mathrm{F}$ test and Duncan test's New Multiple Range Test (DNMRT) at the 5\% significance level.

Treatment in this study are:

$\mathrm{A}=$ Wheat Varieties Jarissa

$\mathrm{B}=$ Wheat Varieties Dewata

$\mathrm{C}=$ Wheat Varieties 1247

$\mathrm{D}=$ Wheat Varieties Selayar

$\mathrm{E}=$ Wheat Varieties SO1

\section{Implementation Research Flour making}

Making flour from wheat varieties Jarissa, Dewata, 1247, Selayar and SO1 begins with sorting the wheat seed that has been collected. Sorting is aiming to separate the rotten and shriveled seeds, with a good grain. Grain of wheat consists of three parts, namely the skin part, endosperm part and germ part. The skin of the wheat seed was not easy to separate because it is an integral of wheat seed, but the skin can usually be separated by milling process

In this study, millingis done by a traditional milling using a mortar and rice pestle. First - all wheat seeds is soaked \pm $20 \%$ of the weight of wheat, then drained and put in a mortar and then polished. After that, dry it with sunshine, to easily removing the skin which had been detached from grain.

Then dried grain milling is soaked around \pm 20 hours with a ratio of $1: 1$. Then dried again in the sunshine. Then dried grain milled using a blender. Wheat that has been milled, then sieve with 80 mesh sieve to obtain flour.

\section{Observation}

The observations conducted toward the physical analysis of wheat flour in the form of yield, water absorption, oil absorption, the appearance of starch granules and gelatinization temperature. Chemical analysis such as moisture content, protein content, fat content, ash content, crude fiber content, carbohydrate content by the method of difference, starch and gluten contents

\section{RESULT AND DISCUSSION}

Results of analysis of yield and functional properties of wheat flour can be seen in Table I.

Analysis of the results obtained flour yield ranges from 45.45 to $50.00 \%$. Highest yield value contained in Jarissa varieties and 1247 varieties. Lowest yield values contained in the varieties of the Dewata.

The results of water absorption ranges from 49.27 to $69.85 \%$. Highest value found in Selayar varieties and the lowest value contained in 1247 varieties. According Bogasari [8], wheat flour has a water absorption ranges from $60-64 \%$ including hard flour and it's the most excellent quality. So that it is suitable for the manufacture of highquality bread. Meanwhile wheat flour has a water absorption ranges from 58-60\% including medium hard flour. 
TABEL I

YIELD AND FUNCTIONAL PROPERTIES OF WHEAT FLOUR

\begin{tabular}{lcccc}
\hline & & \multicolumn{3}{c}{ Functional Properties } \\
\cline { 3 - 5 } (Varieties) & $\begin{array}{c}\text { Rendemen } \\
(\%)\end{array}$ & $\begin{array}{l}\text { Water } \\
\text { Absorption } \\
(\%)\end{array}$ & $\begin{array}{c}\text { Oil } \\
\text { Absorption } \\
(\%)\end{array}$ & $\begin{array}{c}\text { Gelatinization } \\
\text { temperature } \\
\left({ }^{\circ} \mathrm{C}\right)\end{array}$ \\
\hline Jarissa & 50,00 & 65,90 & 17,67 & 65,67 \\
Dewata & 45,45 & 59,95 & 18,33 & 65,00 \\
1247 & 50,00 & 49,27 & 19,67 & 66,00 \\
Selayar & 47,83 & 69,85 & 16,00 & 67,00 \\
SO1 & 47,66 & 51,20 & 15,67 & 65,67 \\
\hline KK $(\%)$ & - & 7,13 & 6,44 & 1,46 \\
\hline
\end{tabular}

Jarissa flour varieties and varieties of Selayar described based on the water absorption is higher than the water absorption of wheat flour from Bogasari Cakra Kembar. So that the flour varieties of Jarissa and Selayar are suitable for bread making. The Flour varieties of Dewata described based on the water absorption, its including the amount of water absorption on flour from Bogasari Segitiga Biru.

So that the flour from the Dewata varieties are well suited for making bread, noodles, kind of cakes and biscuits. Meanwhile the varieties of wheat flour 1247 and SO1 are lower based on the water absorption of medium hard flour, so that the flour varieties of 1247 and SO1 are suitable for the manufacture in any kinds of cakes and biscuits making.

The results of oil absorption ranges from 15.67 to $19.67 \%$. 1247 varieties arethe highest value and SO1 varieties as the lowest value. Higher and higher of the oil absorption of wheat flour it caused lower and lower the quality of the wheat flour obtained, because if the flour oil absorption is high, then the product is produced from the wheat, it will be quickly becoming rancid and not durable if stored

The results of gelatinization temperature ranges from 65.00 to $67.00^{\circ} \mathrm{C}$. The highest value found in varieties of Selayar and lowest values found in varieties of Dewata. Gelatinization temperature is a temperature range in which the gelatinization process perfectly happens from the beginning to the end [9].

During starch gelatinization process, occuring a change in viscosity of starch suspension. In generally, changes in viscosity during starch gelatinization process is during the heating and cooling phases. When the starch suspension is heated gradually, the kinetic energy of the water molecules will weaken and break into the intermolecular hydrogen bonding of amylose / amylopectin crystalline granule so that compactness disrupted. This caused the hydrogen bonding of water gradually penetrate into the starch granules and makes the starch granules swell [10].

Gelatinization temperature of each starch is different and it's a range. This is because the population of granules that various in size, shape and energy required to inflate. By increasing heating temperature above the gelatinization temperature, the starch granules will be expanded and will not be able to hold water anymore. As a result, the starch granules will burst and amylose and amylopectin molecules will blend with the water phase [10].
The appearance of some varieties of wheat starch granules belowusing a Trinokuler light microscope with $400 \mathrm{X}$ magnification and dilution $5 \mathrm{gram} / 100 \mathrm{ml}$ of water, can be seen in Figure 1.
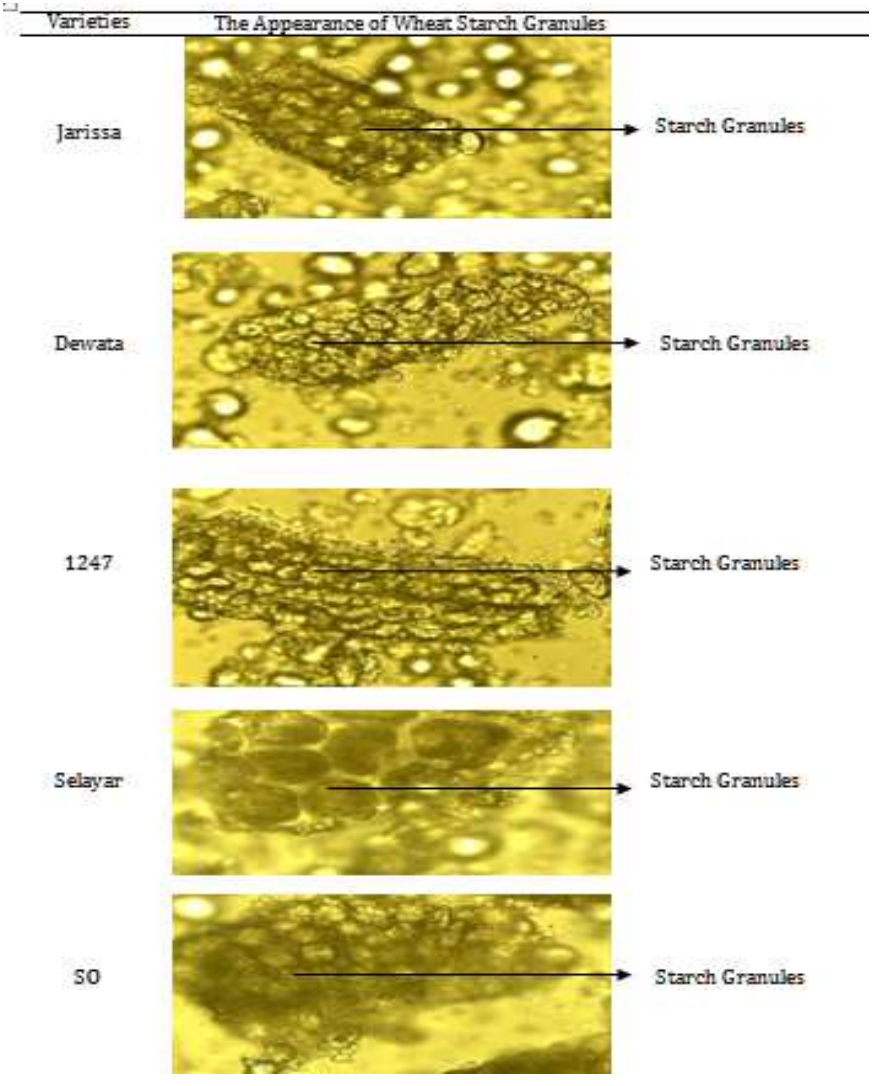

Fig. 1The Appearance of Starch Granules of $400 \times$ Magnification

From Figure 1 it can be seen the difference between the form of flour starch granules of each -each variety which are shown with a microscope. According Kusnandar [10], starch is a reserve carbohydrate that is found in many plants and is the second largest component of carbohydrate after cellulose. Starch contained in granular form (powder). Starch granules are white, shiny, odorless and tasteless. Starch granule has a crystalline structure consisting of an crystal unit and an amorphous unit. Starch granule is composed by two main polysaccharide components, namely amylose and amylopectin. Starch grains showed in the microscope seemed to have a very regular crystal structure.

Chemical Properties of Wheat Flour The results of analysis of chemical properties of wheat flour can be seen in Table 2.

From the analysis of the water content of the flour obtained ranges from 9.48 to $14.75 \%$ of the dry weight (b/k). The highest value found in varieties in 1247 and the lowest value on Selayar varieties. The moisture content obtained fit with SNI qualification wheat flour as a food ingredient [11] is a maximum $; 14.5 \%$ of wet weight $(\mathrm{w} / \mathrm{w})$.

The water content for flour products are expected not too high because it will cause to rapid destruction of the material. Grain flour is very delicate and a very wide surface so that causing hygroscopic of the material which is easy to become moist due to easily absorb of water [12]. 
TABLE II

CHEMICAL PROPERTIES OF WHEAT FLOUR

\begin{tabular}{lcccccccc}
\hline \hline \multirow{2}{*}{ Varieties } & \multicolumn{8}{c}{ Parameter } \\
\cline { 2 - 8 } & $\begin{array}{c}\text { Water } \\
(\%)\end{array}$ & $\begin{array}{c}\text { Ash } \\
(\%)\end{array}$ & $\begin{array}{c}\text { Fat } \\
(\%)\end{array}$ & $\begin{array}{c}\text { Crude Fiber } \\
(\%)\end{array}$ & $\begin{array}{c}\text { Carbohydrate } \\
(\%)\end{array}$ & $\begin{array}{c}\text { Starch } \\
(\%)\end{array}$ & $\begin{array}{c}\text { Protein } \\
(\%)\end{array}$ & $\begin{array}{c}\text { Gluten } \\
(\%)\end{array}$ \\
\hline Jarissa & 10,02 & 1,45 & 2,24 & 3,46 & 71,55 & 53,00 & 14,75 & 50,09 \\
Dewata & 12,00 & 1,75 & 2,59 & 3,11 & 67,00 & 51,92 & 16,66 & 13,37 \\
1247 & 14,75 & 2,15 & 2,50 & 2,56 & 66,06 & 50,86 & 14,54 & 12,71 \\
Selayar & 9,48 & 1,63 & 2,15 & 2,73 & 73,60 & 46,08 & 13,13 & 28,57 \\
S01 & 12,24 & 1,87 & 2,34 & 3,13 & 69,59 & 42,74 & 13,97 & 35,36 \\
\hline KK $(\%)$ & 1,36 & 4,53 & 8,01 & 10,59 & 1,4 & 3,41 & 6,74 & 13,28 \\
\hline
\end{tabular}

The water content affects water absorption and starch gelatinization which will influence the elasticity of the dough to produce a soft texture of bread and noodle. Higher and higher the moisture content of wheat flour so that it will be lower the water absorption of the flour. This happens because the water absorption capacity of the flour is reduced when water contents in the flour are too high or saved in a damp storage. If the water content of food is reduced, the concentration of compounds - compounds in foods such as fats, proteins, carbohydrates and minerals will increase [13].

The ash content of flour produced ranges from 1.45 to $2.15 \%(\mathrm{w} / \mathrm{k})$. The highest value found in varieties 1247 and the lowest value on Jarissa varieties. The ash content obtained is not eligible SNI wheat flour as a food ingredient [11] is a maximum ; $0.6 \%$ (w / w). It can be caused by the high mineral content in wheat flour produced in this study. In addition, the magnitude of the existing mineral content in wheat flour can affect the resulting color of flour. Existing mineral content in wheat, among others are $\mathrm{Ca}, \mathrm{Cl}, \mathrm{P}, \mathrm{K}, \mathrm{Na}$, $\mathrm{Mg}, \mathrm{S}, \mathrm{Zn}, \mathrm{Mo}, \mathrm{Fe}, \mathrm{Mn}, \mathrm{Cu}$ and others - others [1].

The high of ash content could be due to the process of milling wheat endosperm which milled not close to pith but close to the skin pith.Because of the endosperm is the largest part of the grain of wheat $(80-83 \%)$ that contain lots of protein, starch and water. In the milling process, this part is to be taken as much as to convert into flour with a certain level of delicacy. In this section there is also a gray substance containable will be smaller when approaching the pith and will be even greater if it's close to the skin [14].

The ash content in the wheat flour will affects the end product, such as color product (crumb color of the bread, color of noodle) and dough stability level. Beside that,it can make gluten easily broken so it doesn't inflate perfectly. Higher and higher the ash content it will make worse the quality of the flour. On the other hand, the lower of the ash content it will make the better quality of the flour [15].

According Sudarmadji [16], ash is an inorganic substance residue from burning a food ingredient. Ash content indicates the amount of the mineral content in the food.

The fat content of wheat flour produced ranges from 2.15 to $2.59 \%(\mathrm{w} / \mathrm{k})$. The highest value found on the variety of Dewata and the lowest value on Selayar varieties. But the fat content obtained was noin terms of wheat flour SNI as a food ingredient [11] so it can not be compared to the fat content of the flour produced in this study.

But according Maitalia [17], where the existence of the fat is very important in the formation of bread dough. Fat affects the texture of the products and the different types of fat have different effects on dough products. Winarno [13], stated that the presence of fat or water mass formation of fibers from wheat gluten which is dense and hard can be prevented. Thus, gluten fibers become shorter gluten, so it ends up being more tender product.

The crude fiber content of flour produced ranges from 2.56 to $3.46 \%(\mathrm{w} / \mathrm{k})$. The highest value found in Jarissa varieties and the lowest value in 1247 varieties. Nevertheless, the crude fiber content obtained was no in terms of wheat flour SNI as a food ingredient [11] so it can not be compared with the crude fiber content of flour produced in this study.

According Kartasapoetra [18], fiber in food is not digestible polysaccharides elements (cellulose, hemicellulose and pectin), insoluble in water, generally tasteless or bitter. Fibers derived from the cell walls of many different vegetables and fruits.

The crude fiber has an important role in the process of digestion. According Muchtadi [19], the crude fiber has a greater ability to hydrolyze components of food compared to digestive enzymes. Carbohydrate content of the resulting flour ranged from 66.06 to $73.60 \%$ (w/k). The highest value found in Selayar varieties and the lowest value on the variety 1247. Nevertheless, carbohydrate levels obtained was noin terms of wheat flour SNI as a food ingredient [11] so it can not be compared to the carbohydrate content of flour produced in this study. But carbohydrates have an important role in determining the characteristics of foodstuffs.

Carbohydrates are one of the main energy source for the body. Carbohydrate components found in many food products are starch, sugar, pectin and cellulose. In the body, carbohydrates help to metabolize protein and fat. The higher the protein content, ash content, fat content and moisture content of the product, so the product is lower in carbohydrate content [13].

The starch content of wheat flour produced ranges from 42.74 to $53.00 \%(\mathrm{w} / \mathrm{k})$. The highest value found in Jarissa varieties and the lowest value contained in SO1 varieties. Nevertheless, starch content obtained was no in terms of wheat flour SNI as a food ingredient [11] so it can not be compared with the starch content of flour produced in this study.

The starch in the flour is able to determine the properties of flour because starch consists of two fractions namely water-soluble fraction is called amylose and insoluble fraction called amylopectin. The smaller the content of amilosanya or higher amylopectin content, so the lower the water absorption of the material [13].

The protein content of wheat flour produced ranges from 13.13 to $16.66 \%(\mathrm{w} / \mathrm{k})$. The highest value found on the variety of Dewata and the lowest value contained in Selayar varieties. Protein content obtained SNI qualificationof wheat flour as a food ingredient [11] is at least $7.00 \%$ of wet weight.

The protein contains in wheat flour in this study including hard wheat flour. The hard wheat flour is high protein flour with a protein content of $12-14 \%$, water content from 14.10 to $14.50 \%$ of wet weight [15].

Wheat flour produced in this study is based on protein content when viewed based on the same type of flour Cakra Kembar Bogasari and type of flour is suitable for making 
ahigh quality bread and noodles. Nevertheless, in the manufacture of high-quality bread; gluten becomes the most influential.

According to the U.S. wheat Assacietes [20], the protein quality is more important factor in the formation of the properties of flour when making bread and cakes. Protein in the form of gluten in the flour used to form a good detention structure of gas barrier so making bread and cake volume becomes larger [21].

The gluten content of wheat flour produced ranges from 12.71 to $50.09 \%$. The highest value found in Jarissa varieties and the lowest value contained in the 1247 varieties. Percentage level of gluten content of flour obtained in this study are part of the percentage of protein content in the wheat flour results of this study.

The uniqueness of wheat flour is containing gluten which not had by other types of flour. Gluten is a compound of the flour that is both supple and elastic, which is required in the manufacture of bread in order to inflate well, which it can decisive the viscosity of noodle as a role in making noodles and shell eggs of martabak that does not be rive easily. Generally, the gluten content determine of wheat flour protein content, the higher the gluten content, the higher the protein content of the flour. The gluten content in the flour,it determines the quality of the end food products, is highly dependent on the type of grain [8].

The protein contained in wheat flour does not dissolve in water. Proteins are not soluble in water called gliadin and glutein. Glutein is a form of protein that is not soluble in water if the flour is heated and mixed with water. Glutein can be extracted by washing with water until the starch is lost.The extracted glutein has an elastic properties and cohesion. If gliadin and glutenin separated from the gluten therefore gliadin will be like syrup substance which coagulates and bound to each other and produced a solidness that will enlarge the power of the material texture [22].

On wheat, gluten content does not spread evenly on a whole grain endosperm of wheat seeds, but centered in the part of the protein body that contain fat tissue. This section takes a step as a center for the synthesis of gliadin and glutenin. Gluten makes dough elastic and can expand because it is airtight [23].

\section{CONCLUSIONS}

Conclusion includes several things are:

(1) The results of physical and chemical tests of some varieties of wheat flour wheat showed that wheat varieties Jarissa, Dewata, 1247, Selayar and SO1 have a protein content ; 13.13 to $16.66(\% \mathrm{w} / \mathrm{k})$, so it is classified into the hard wheat flour which used for making noodles and bread.

(2) Flour from Jarissa varieties, Dewata varieties and selayar varieties analyzed by their physical and chemical properties of the water absorption, ash content, protein content and gluten, third of these flour could be made sweet bakery products. Meanwhile 1247 varieties and SO1 varieties analyzed by the physical and chemical properties of the water absorption, ash content, protein content and gluten, Both of these varieties of flour is made for instant noodles products.

\section{SUGGESTION}

To get better results and a high yield process, it needs to be improved milling, soaking, drying and flouring. In addition, the flour produced from each of variety of wheat grown in the area of West Sumatra needs to be promoted, to increase grain commodities in West Sumatra that could create new job opportunities for local farmers and could reduce the number of national import.

\section{ACKNOWLEDGMENT}

The author would like to thank the PT. Indofood Sukses Makmur, Tbk. On funding research in the frame work program NUGRAHA INDOFOOD RESEARCH 2012 2013, research was funded / sponsored by PT Indofood Sukses Makmur, Tbk.

document is a template. An electronic copy can be downloaded from the conference website. For questions on paper guidelines, please contact the conference publications committee as indicated on the conference website. Information about final paper submission is available from the conference website.

\section{REFERENCES}

[1] Nurmala, T. 2003. Serealia Sumber Karbohidrat Utama. Rineka Cipta,Bandung.

[2] Anonim. 2009. Rubrik Gizi dan Kesehatan Tabloid Koki Edisi 00147April2009

http://nikmeh.multiply.com/journal/item/1?\&show_interstitial=1\&u= $\% 2$ Fournal\% 2 Fitem (5 Maret 2012).

[3] Batan. 2012. Penelitian Pemuliaan Tanaman Gandum dengan Teknik Mutasi.http://www.batan.go.id/patir/_kerma/pert/bogasari/bogasari.ht $\mathrm{ml}$.

[4] Pusat Studi Gandum UKSW. 2008. Refleksi Sewindu (8 Tahun) Pengembangan Gandum Indonesia.Di dalam Seminar Nasional Gandum. FakultasPertanian, Universitas Kristen Satya Wacana, Salatiga.

[5] Salim, E. 2011. Mengubah Singkong Menjadi Tepung Mocaf. Lily Publisher, yogyakarta.

[6] Puspita, A.A.D. 2009. Analsis Daya saing dan Strategi Pengembangan Agribisnis Gandum Lokal di Indonesia. [Skripsi]. Bogor. Fakultas Ekonomi dan Manajemen Institut Pertanian Bogor.

[7] Ditjen Tanaman Pangan. 2008. Bahan Publikasi :Pengembangan Gandum. Jakarta :Departemen Pertanian.

[8] Bogasari, 2011.(http://www.bogasari.com., 2011). (21 November 2012).

[9] Muchtadi, T., Purwiyatno dan Basuki A. 1988. Teknologi Pemasakan Ekstrusi. Pusat Antar Universitas Institut Pertanian Bogor. Bogor.

[10] Kusnandar, F. 2010. Kimia Pangan: Komponen Makro. Dian Rakyat. Jakarta.

[11] SNI 01-3751-2006. Tepung Terigu sebagai makanan. Jakarta. Dewan Standarisasi Nasional Jakarta.

[12] Dwiari, RS.,Asadayanti, DD., Nurhayati, Sofyaningsih, M., Yudhanti, AR,.Yoga, W. 2008. Teknologi Pangan Untuk Sekolah Menengah Kejuruan Kelompok Teknologi Indusrti. Penerbit Direktorat Pembinaan Sekolah Menengah Kejuruan. DEPDIKNAS.

[13] Winarno, F.G. 2002. Kimia Pangan dan Gizi. PT. Gramedia Pustaka Utama, Jakarta.

[14] Anonim. 2012. Gandum. Wikipedia bahasa Indonesia, Ensiklopedia Bebas. http://id.wikipedia.org/wiki/Gandum (5 Maret 2012).

[15] Bogasari. 2007. Seputar Tepung Terigu.

[16] http://www.bogasari.com/tentang-kami/seputar tepung terigu.aspx (4 Juni 2012).

[17] Sudarmadji, S., Haryono dan Suhardi. 1997. Prosedur Analisa untuk Bahan Makanan dan Pertanian. Liberty, Yogyakarta.

[18] Maitalia, D. 2007.Pengaruh Formulasi Tepung Terigu, Singkong dan Kedelai Terhadap Sifat Fisik, Kimia dan Organoleptik Roti Manis. [Skripsi]. Padang. Fakultas Pertanian Universitas Andalas.

[19] Kartasapoerta, G., Marsetyo, H. 2002. Ilmu Gizi. Jakarta. Rieneka Cipta. 
[20] Muchtadi, D. 1989.Evaluasi Nilai Gizi Pangan. Departemen pendidikan dan Kebudayaan Direktorat Jenderal Pendidikan Tinggi Pusat Antar Universitas Pangan dan Gizi. Bogor. Institut Pertanian Bogor.

[21] U.S, Wheat Associetes. 1983. Pedoman Pembuatan Roti dan Kue. Jakarta: Djambatan.

[22] Bogasari. 2004. Referensi Industri.

[23] http://www.bogasariflaour.com/ref_ind.htm. (21 September 2012).

[24] Parker, R. 2003. Introduction to Food Science. Delmar Thompson Learning, United States. Desrosier, N.W. 1988. Teknologi Pengawetan Pangan. Penerjemah: Muchji Muljohardjo. Edisi Ketiga. Jakarta: Universitas Indonesia. 